Ferrell, J. and Greer, C. (2009) 'Global Collapse and Cultural Possibility', in Crime Media Culture: An International Journal, 5, 1: 5-8.

\title{
Global Collapse and Cultural Possibility
}

This fifth volume of $C M C$ comes along at a particularly precarious time in global history. The current crisis of global capitalism is of course a crisis of human meaning and sustainability as well; more is at stake, always, than markets. As global capitalism shudders under the weight of its accumulated contradictions, other dimensions of human life are shaken as well: local cultures, familial arrangements, immigrant opportunities, even the provision of daily sustenance. And if Marx and Merton were even half right, these tremors will rattle the social order in ways that produce new strains on legitimate achievement, new tensions between social classes, new experiences of perceived deprivation and material want, and so new sorts of crime and predation. Mix all this with the global mediasphere-with a live-on-demand mediascape that confounds causes and consequences, images and their effects-and it's easy to imagine the madness that may lie ahead.

Yet a shuddering social order can shake loose new hopes and possibilities as well. As seen in the recent U.S. presidential election, a well-timed social crisis can help produce results unimaginable decades before-perhaps even days before. The media saturation of daily life can convert every moment of progressive resistance into a made-fortelevision commodity; but a citizenry armed with video cameras and cell phones can also invent the sort of instantaneous communication that makes meaningful political resistance a viable alternative. A world where commodity consumption no longer defines everyday life can punch a whole in citizens' acquired sense of self; but the possibilities emergent in that world can also begin to fill that hole, perhaps, with new sorts of economic and cultural self-sufficiency. Now is no time for despair, or for drawing back from the task of critical, culturally engaged analysis. Dangerous times demand at least a modicum of intellectual courage.

It is in this cultural context, and in this spirit, that we move into $C M C^{\prime}$ s fifth year of exploring media, crime, culture, and politics. Media and politics have, of course, for decades been inseparable; yet with the 2008 U.S. presidential election the use of new and alternative media as tools for political campaigning was taken to a new level. Clearly understanding that 'traditional' or 'conventional' media forms - print and broadcast news, billboard and television advertising - no longer suffice to capture the attention, still less to stimulate the imagination, of the young voters whose contribution were to be so crucial, the Democratic campaign fully embraced the rapidly expanding and diversifying media terrain. Conventional print and broadcast adverts were accompanied by myriad, and expensive, interventions in cyber worlds. Spoken addresses and campaign ads were posted on Facebook and YouTube. In surely the first example of ingame political advertising, the billboards surrounding the virtual track in the X-Box 360 
racing game Burnout Paradise included 'official' Obama advertisements; computer space was bought for 18 games in total, including Guitar Hero and Madden '09. Obama even made an appearance in Second Life - a virtual world created, populated and maintained entirely by its (virtual) residents, many of whom gathered to greet the presidential candidate clad in computer-generated Obama T-Shirts.

The irony of an established political party using such new and alternative media, routinely criticized and frequently condemned for their deleterious effects on susceptible minds, is not difficult to see. Making a mockery of the kinds of positivistic reductionism that insists upon some straightforward, quantifiable relation between media consumption and human action, this political strategy highlighted the complex connections between media and culture, politics and society, democracy and identity. Hyperreality and simulation, the blurring of boundaries between the represented and the real, the infinite hall of mediatised mirrors - notions first conceptualized by postmodernists and today deployed, albeit with due caution, by critical media theorists and cultural criminologists alike - were now appropriated by the political mainstream. And to considerable effect; as one gaming enthusiast exclaimed, 'Games just get realer and realer' (Glendinning, 2008).

Our attention to the global and the political in this editorial is reflected in the contributions to this issue. Stephanie Kane's analysis of stencil graffiti around urban waterscapes in post-crisis Argentina conceptualizes such moments of socially productive 'semiotic disobedience' as a means of enacting collective memory and political dissent. David Brotherton and Luis Barrios's ethnographic research on the forced repatriation of Dominican deportees explores the social psychological effects of cultural estrangement and stigma among the rapidly escalating numbers of 'non-citizens' expelled from the United States. Lizzie Seal's feminist analysis of the British tabloid Daily Mirror's campaign for the release of convicted killer Edith Chubb illustrates a particular imaginary of gender, class and power relations in post-war Britain. David Altheide's exploration of 'moral panic' traces its transition from an exclusively academic concept to a political and journalistic label used daily, if often in contradictory ways, in the US and British media. And Craig Ritchie, in the second of two photo essays on the Cambodian Rail System (see also CMC 4, 3), uses documentary photography to portray the quotidian adaptive uses of the railway and its surrounds - decimated by years of civil war - by Cambodian citizens.

Amidst a crisis of global proportions, then, our scholarship remains and must remain global as well-but all the while engaging with the cultural particulars that animate situations of injustice, dissent, and communication. Exploring the intersections of crime, media, and culture will increasingly require intellectual, polemical, theoretical, and empirical sensibilities attuned to these contested intersections of the local and global. Be assured that our commitment to promoting the best in this sort of critical international scholarship - a commitment clearly stated in our first editorial some five years ago-has only been galvanized by recent world events. Five years on, we repeat 
also our invitation for you to contribute to the discussion and to join us in our exploration.

Here at $C M C$, we're confronting something of a crisis ourselves. After four successful volumes of the journal, Yvonne Jewkes, one of $C M C^{\prime}$ 's founding editors, has now decided to move on to fresh intellectual challenges. While Yvonne will remain active with $C M C$ as an Associate Editor, our sense of crisis is not quite assuaged. Yvonne was not only one of the journal's founding editors; she was the person who first imagined that $C M C$ might come into existence, and who set in motion the process by which it did. The journal, and all those who have published in it or will do so, owe Yvonne an inestimable debt of gratitude. As editors, we have great difficulty in imagining the journal without her.

As with the world crisis, though, emergent problems spawn new possibilities, and so with this fifth volume of $C M C$ we are pleased to welcome Mark Hamm as editor. A steadfast supporter of the journal from the start, an International Advisory Board member and subsequently an Associate Editor, Mark brings to the journal a keen sense of continuity and perspective. More than this, his extensive scholarly work on extremist subcultures, popular music, immigration politics, and ethnic identity adds important new directions to the journal's editorial trajectory. We are as happy to have Mark joining the journal as we are sad to see Yvonne's departure from it, and we look forward to his editorial contributions in the volumes to come.

Probably should make a decision about the Article of the Year - I can add something on this above, but have you any thoughts on which it might be. And do we want an earlycareer scholar, or just the best article?

\section{References.}

Glendinng, L. (2008) Obama's new advertising pitch: video games, blog posted on Guardian Unlimited, October $15^{\text {th }}$, available at:

http://www.guardian.co.uk/world/deadlineusa/2008/oct/15/uselections2008barackobama 